\title{
DINARIC KARST INTERMITTENT RIVERS HARBOUR SOME RARE MAYFLIES (INSECTA, EPHEMEROPTERA)
}

\author{
Marina Vilenica ${ }^{1 *}$, Mario Rumišek ${ }^{2}$, Fran Rebrina $^{2}$, \\ Renata MatoničKin KepčiJa ${ }^{2}$, Kristian MedaK ${ }^{2}$, \\ Vesna Gulin ${ }^{2} \&$ Andreja Brigić ${ }^{2}$ \\ ${ }^{1}$ Faculty of Teacher Education, University of Zagreb, Petrinja, Croatia \\ ${ }^{2}$ Department of Biology, Faculty of Science, University of Zagreb, Zagreb, Croatia
}

Vilenica, M., Rumišek, M., Rebrina, F., Matoničkin Kepčija, R., Medak, K., Gulin, V. \& Brigić, A.: Dinaric karst intermittent rivers harbour some rare mayflies (Insecta, Ephemeroptera). Nat. Croat., Vol. 30, No. 2, 377-387, Zagreb, 2021.

While investigating the aquatic macroinvertebrate fauna of four intermittent Dinaric karst rivers in Croatia, we confirmed or recorded new distribution data and ecological features for several mayfly species rare in Croatian freshwater habitats: Nigrobaetis niger (Linnaeus, 1761), Procloeon pennulatum (Eaton, 1870) and Paraleptophlebia werneri Ulmer, 1920. To our knowledge, this is the first record of $N$. niger in intermittent lotic habitats. We discuss their substrate preferences in the studied habitats as well as their relationships with measured physico-chemical water parameters. The newly obtained results confirm that our knowledge about Croatian mayfly fauna and species ecological requirements in intermittent Mediterranean rivers is still incomplete and is increasing with systematic studies.

Key words: Ephemeroptera, IRES, temporary habitats, lotic habitats, environmental parameters, Nigrobaetis niger, Procloeon pennulatum, Paraleptophlebia werneri

Vilenica, M., Rumišek, M., Rebrina, F., Matoničkin Kepčija, R., Medak, K., Gulin, V. \& Brigić, A.: Dinarske krške povremene tekućice kriju neke rijetke vrste vodencvjetova (Insecta, Ephemeroptera). Nat. Croat., Vol. 30, No. 2, 377-387, Zagreb, 2021.

Tijekom istraživanja slatkovodnih beskralješnjaka povremenih tekućica dinarskog krša u Republici Hrvatskoj, potvrdili smo ili zabilježili nove podatke o rasprostranjenosti i ekološkim značajkama nekoliko vrsta vodencvjetova koje se smatraju rijetkima u hrvatskim slatkovodnim staništima: Nigrobaetis niger (Linnaeus, 1761), Procloeon pennulatum (Eaton, 1870) i Paraleptophlebia werneri Ulmer, 1920. Prema našim spoznajama, N. niger je po prvi puta zabilježen u povremenim tekućicama. Osim rasprostranjenosti, $\mathrm{u}$ ovom radu raspravljamo i o njihovom izboru mikrostaništa te odnosu $s$ fizikalno-kemijskim parametrima vode $\mathrm{u}$ istraživanim povremenim tekućicama. Ovi rezultati potvrđuju da naše znanje o fauni vodencvjetova Republike Hrvatske te o njihovim ekološkim zahtjevima u povremenim tekućicama još uvijek nije potpuno te se povećava sa svakim sustavno provedenim istraživanjem.

Ključne riječi: Ephemeroptera, IRES, povremena lotička staništa, okolišni čimbenici, Nigrobaetis niger, Procloeon pennulatum, Paraleptophlebia werneri

\section{INTRODUCTION}

Intermittent rivers and streams (IRES) are hydrologically highly dynamic and complex freshwater ecosystems that periodically cease to flow and run dry. They

\footnotetext{
* corresponding author; email: marina.vilenica@ufzg.hr
} 
occur worldwide, covering more than half of the global river network. They are also common in Europe, especially in the Mediterranean region, where they are even dominant in some river networks (LARned et al., 2010; SKoulikidis et al., 2017; TocknER et al., 2009). Due to climate change and increasing demands for water, intermittent lotic habitats are expanding worldwide, and there is evidence that some perennial rivers changed their hydrology becoming intermittent during the past few decades (GLEICK, 2003). Although intermittent have lower taxonomical diversity than perennial rivers and streams, many studies showed that they can also support high biodiversity (see in STUbington et al., 2018). Aquatic taxa of IRES exhibit traits associated with resistance (e.g. protection from desiccation, diapauses) or resilience (e.g. efficient dispersal, various locomotion types) to flow intermittence (LEIGH et al., 2015).

Mayflies are an amphibious insect order, spending their nymphal life in aquatic habitats and adult life in terrestrial habitats. Their nymphs can be found in both standing and running waters, where they are dependent on a wide range of physical and chemical water parameters, such as oxygen concentration, $\mathrm{pH}$, water temperature, water velocity, substrate composition, and nutrient availability (e.g. BAUERNFEIND \& Soldín, 2012; Vilenica et al., 2018a, 2017a, 2016). Very often, mayflies are among the most abundant groups of aquatic macroinvertebrates in freshwater habitats, having an important role in secondary production as a significant food source for a wide range of aquatic and terrestrial predators (ElLIOTT et al., 1988; SARTORI \& Brittain, 2015). Due to their high sensitivity to habitat alterations (Firmiano et al., 2017; ViLENiCA et al., 2019, 2020), they are widely used in bio-monitoring programmes worldwide (SARTORI \& BRITTAIN, 2015).

Mayfly-focused research in Croatia started less than a decade ago and revealed a relatively high number of mayfly species in Croatian freshwater habitats (VILENICA et al., 2021). Nevertheless, there are still gaps in our knowledge about the distribution and ecological requirements of many species (VILENICA et al., 2021), and based on the current knowledge, some of them can even be considered rare. As there is still much to be learned about the ecology and biodiversity of IRES, we have conducted research in four intermittent Mediterranean karst rivers in Croatia. The aim of this study is: 1) to present the distribution of several rare mayfly species recorded in IRES, based on literature and new data; and 2) to provide further insight into their habitat choice and relationship with environmental factors.

\section{MATERIAL AND METHODS}

\section{Study area}

Croatian territory extends over two limno-ecological regions: the Dinaric Western Balkan Ecoregion (ER5) and the Hungarian Lowlands Ecoregion (ER11) (NN 66/16, 2016). Our study area is in the Croatian part of ER5. The climate of the area is temperate humid with hot summer (Cfa, Köppen classification) with the average temperature of the warmest month above $22^{\circ} \mathrm{C}$ (ŠEGOTA \& FILIPČIÍ, 2003). The average annual air temperature is around $14^{\circ} \mathrm{C}$ and the average annual rainfall is around $1000 \mathrm{~mm}$ (ZANinović et al., 2008). This study encompassed four geographically close intermittent rivers - the Krčić, Čikola, Guduča and Miljašić Jaruga Rivers (Fig. 1, Tab. 1). Along each river, three study sites were chosen, with increasing distance from the river source $(1=$ closest to the source, 3 = furthest from the source). 
Tab. 1. Characteristics of the study sites along four intermittent Dinaric karst rivers in Croatia.

\begin{tabular}{|c|c|c|c|c|c|c|}
\hline River & \multicolumn{3}{|c|}{ Krčić } & \multicolumn{3}{|c|}{ Guduča } \\
\hline Locality & 1 & 2 & 3 & 1 & 2 & 3 \\
\hline Coordinates, $\mathrm{N}$ & 44.02734 & 44.02761 & 44.04190 & 43.92848 & 43.92358 & 43.89061 \\
\hline Coordinates, E & 16.31899 & 16.30671 & 16.25358 & 15.83178 & 15.80045 & 15.79960 \\
\hline $\begin{array}{l}\text { Substrate } \\
\text { composition (\%) }\end{array}$ & $\begin{array}{c}60 \% \text { phytal, } \\
20 \% \\
\text { mesolithal, } \\
20 \% \\
\text { microlithal } \\
\end{array}$ & $\begin{array}{c}60 \% \text { phytal, } \\
20 \% \\
\text { mesolithal, } \\
20 \% \\
\text { microlithal } \\
\end{array}$ & $\begin{array}{c}40 \% \text { phytal, } \\
40 \% \text { lithal, } 10 \% \\
\text { xylal, } 10 \% \\
\text { psammal }\end{array}$ & $\mid \begin{array}{c}60 \% \text { phytal, } \\
20 \% \\
\text { megalithal, } \\
20 \% \text { mesolithal }\end{array}$ & $\begin{array}{c}20 \% \\
\text { mesolithal, } \\
20 \% \text { xylal, } 60 \% \\
\text { phytal }\end{array}$ & $\begin{array}{c}10 \% \\
\text { microlithal, } \\
10 \% \\
\text { mesolithal, } \\
80 \% \text { phytal }\end{array}$ \\
\hline River & \multicolumn{3}{|c|}{ Čikola } & \multicolumn{3}{|c|}{ Miljašić Jaruga } \\
\hline Locality & 1 & 2 & 3 & 1 & 2 & 3 \\
\hline Coordinates, $\mathbf{N}$ & 43.84345 & 43.84572 & 43.83771 & 44.19420 & 44.20716 & 44.21980 \\
\hline Coordinates, E & 16.25727 & 16.17832 & 16.04927 & 15.27819 & 15.25737 & 15.23919 \\
\hline $\begin{array}{l}\text { Substrate } \\
\text { composition (\%) }\end{array}$ & $\begin{array}{c}80 \% \text { phytal, } \\
20 \% \text { megalithal }\end{array}$ & $\begin{array}{c}60 \% \text { phytal, } \\
30 \% \text { argylal, } \\
10 \% \text { akal }\end{array}$ & \begin{tabular}{|c|}
$10 \%$ phytal, \\
$20 \%$ \\
microlithal, \\
$20 \%$ xylal, $50 \%$ \\
megalithal
\end{tabular} & $\mid \begin{array}{c}70 \% \text { phytal, } \\
30 \% \text { mesolithal }\end{array}$ & $\begin{array}{c}50 \% \text { phytal, } \\
30 \% \\
\text { microlithal, } \\
20 \% \text { argylal }\end{array}$ & $\begin{array}{l}80 \% \text { phytal, } \\
20 \% \text { argylal }\end{array}$ \\
\hline
\end{tabular}

\section{Sampling protocol and species identification}

Aquatic macroinvertebrates, including mayfly nymphs, were collected on April $15^{\text {th }}$ and $16^{\text {th }} 2021$, using a standard benthic macroinvertebrate sampling method, a Surber sampler $(25 \mathrm{~cm}$ x $25 \mathrm{~cm}$, mesh size $500 \mu \mathrm{m})$. At each study site, four replicate samples were collected, proportional to the microhabitats present. Substrates consisted mainly of fine sediment (sand, silt, mud), lithal (stones, gravel), and aquatic vegetation (submerged and emergent); detailed substrate composition of the study sites is presented in Tab. 1.

All samples were immediately preserved in $96 \%$ ethanol, subsequently sorted and identified in the laboratory. Mayfly nymphs were identified using BAUERNFEIND \& Humpesch (2001). Taxonomy follows Waltz et al. (1994) and Bauernfeind \& Soldán (2012). The voucher specimens are deposited in the first author's collection, at the Department of Biology, Faculty of Science, University of Zagreb, Croatia.

At each study site, the following physico-chemical water parameters were measured: water temperature, dissolved oxygen concentration and saturation (using the oximeter WTW Oxi 330/SET), conductivity (with the conductivity meter WTW LF 330), $\mathrm{pH}$ (using the $\mathrm{pH}$-meter WTW ph 330), water body width and depth (using a hand meter/measuring tape) and water velocity (using the SonTek Flow Tracker). Chemical analyses of water were conducted in the laboratory using Standard Analytical Procedure (APHA, 1992) for measuring alkalinity, water hardness, chemical oxygen demand, concentrations of nitrites, nitrates, and orthophosphates (Tab. 2).

\section{Data analysis}

Distribution maps were created in QGIS desktop 3.4.6. Ink (http:/ / www.qgis.org) using literature data and new findings. 
Tab. 2. Physico-chemical water parameters along four intermittent Dinaric karst rivers in Croatia.

\begin{tabular}{|c|c|c|c|c|c|c|c|c|}
\hline \multirow{2}{*}{$\begin{array}{l}\text { Physico-chemical water } \\
\text { parameters/Rivers }\end{array}$} & \multicolumn{2}{|c|}{ Krčić } & \multicolumn{2}{|c|}{ Guduča } & \multicolumn{2}{|c|}{ Čikola } & \multicolumn{2}{|c|}{ Miljašić Jaruga } \\
\hline & Mean & $\begin{array}{l}\text { Standard } \\
\text { deviation }\end{array}$ & Mean & $\begin{array}{l}\text { Standard } \\
\text { deviation }\end{array}$ & Mean & $\begin{array}{l}\text { Standard } \\
\text { deviation }\end{array}$ & Mean & $\begin{array}{l}\text { Standard } \\
\text { deviation }\end{array}$ \\
\hline Water temperature $\left({ }^{\circ} \mathrm{C}\right)$ & 8.4 & 0.3 & 14.5 & 1.1 & 12.1 & 0.4 & 15.0 & 0.5 \\
\hline Oxygen saturation (\%) & 98.8 & 2.6 & 99.8 & 6.7 & 96.8 & 0.9 & 118.0 & 4.2 \\
\hline Dissolved oxygen $(\mathrm{mg} / \mathrm{L})$ & 11.29 & 0.32 & 10.15 & 0.85 & 10.22 & 0.16 & 11.99 & 0.47 \\
\hline $\mathrm{pH}$ & 8.03 & 0.32 & 7.79 & 0.30 & 8.18 & 0.12 & 7.87 & 0.13 \\
\hline Conductivity $(\mu \mathrm{S} / \mathrm{cm})$ & 333 & 13 & 487 & 8 & 489 & 26 & 615 & 16 \\
\hline Water velocity $(\mathrm{m} / \mathrm{s})$ & 0.60 & 0.09 & 0.60 & 0.31 & 0.38 & 0.22 & 0.17 & 0.06 \\
\hline Water depth (cm) & 27 & 10 & 35 & 19 & 35 & 18 & 26 & 16 \\
\hline $\mathrm{COD}\left(\mathrm{mg} \mathrm{O}_{2} / \mathrm{L}\right)$ & 3.03 & 0.71 & 4.62 & 1.19 & 3.77 & 0.67 & 3.45 & 1.69 \\
\hline Nitrates (mg N/L) & 0.319 & 0.166 & 0.230 & 0.175 & 0.187 & 0.097 & 0.199 & 0.108 \\
\hline Nitrites (mg N/L) & 0.000 & 0.000 & 0.039 & 0.051 & 0.009 & 0.005 & 0.013 & 0.003 \\
\hline Phosphates (mg P/L) & 0.017 & 0.002 & 0.024 & 0.012 & 0.009 & 0.007 & 0.022 & 0.007 \\
\hline Alkalinity $\left(\mathrm{mg} \mathrm{CaCO}_{3} / \mathrm{L}\right)$ & 120 & 12 & 143 & 15 & 149 & 19 & 156 & 8 \\
\hline $\begin{array}{l}\text { Water hardness } \\
\left(\mathrm{mg} \mathrm{CaCO}_{3} / \mathrm{L}\right)\end{array}$ & 189.9 & 35.9 & 229.9 & 35.9 & 302.6 & 64.9 & 281.8 & 40.8 \\
\hline
\end{tabular}

Abundances (number of collected individuals) of each of the recorded mayfly species were correlated with physico-chemical water properties data using Spearman's rank correlation coefficient. Analyses were performed using Statistica 13.0 (TIBCO SOFTWARE INC., 2017).

\section{RESULTS AND DISCUSSION}

While investigating the aquatic macroinvertebrate fauna of the four intermittent Dinaric karst rivers in Croatia, we have confirmed or recorded new distribution data and ecological features for several mayfly species rare in Croatian freshwater habitats: Nigrobaetis niger (Linnaeus, 1761), Procloeon pennulatum (Eaton, 1870) and Paraleptophlebia werneri Ulmer, 1920 (e.g. VileniCA et al., 2014, 2015, 2016, 2017b, 2018b, 2020). All three species are considered rare on the European scale, due to their scarcity in several ecoregions. Nigrobaetis niger, a species with Palearctic distribution (BAUERNFEIND \& SOLDÁN, 2012), is considered rare in ER3 (i.e. present only in Italy), ER7 (Eastern Balkans), ER12 (Pontic Province), ER13 (Western Plains) and ER14 (Central Plains). Furthermore, P. pennulatum, a species with Holarctic distribution (BAUERNFEIND \& SOLDÁN, 2012), is rare in ER4 (Alps) and ER8 (Western Highlands) while $P$. werneri, a species with western Palaearctic distribution, is rare in ER10 (the Carpathians) and ER11 (Hungarian Lowlands) (BUfFaGni et al., 2009, 2021).

\section{Nigrobaetis niger (Linnaeus, 1761)}

In this study, rheo- to limnophile N. niger was recorded in the Krčić (study site 3), Čikola (study sites 1 and 2) and Guduča Rivers (study sites 2 and 3) (Figs. 1a, b, c). In previous studies, the species was recorded at four lotic habitats in the Hungarian Lowlands ecoregion (ER11) (the Kraljevec, Čemernica (VILENICA et al., 2015), Danković klada Streams (VILENica et al., 2016), and the Glina River (VIlenica et al., 2015)) 

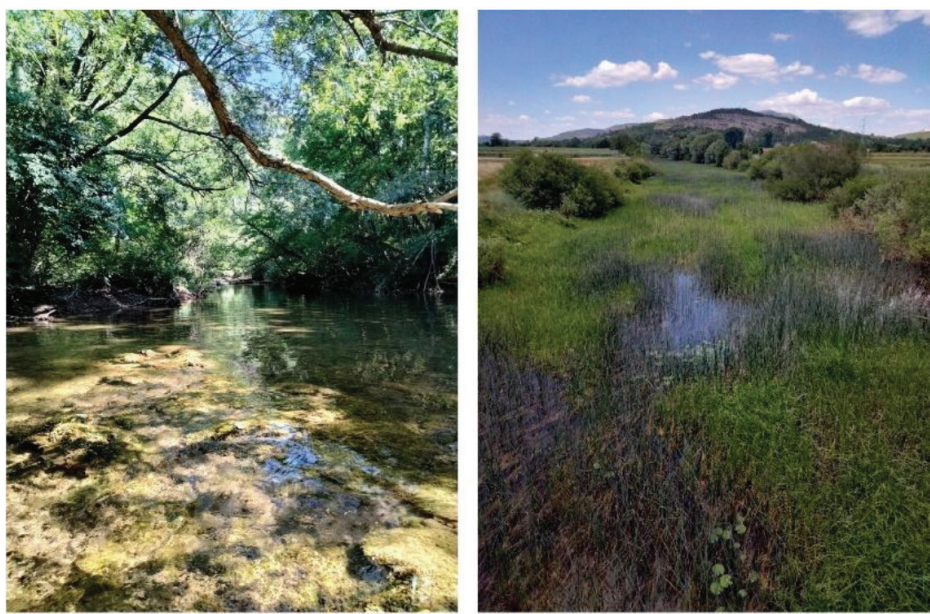

a)

b)
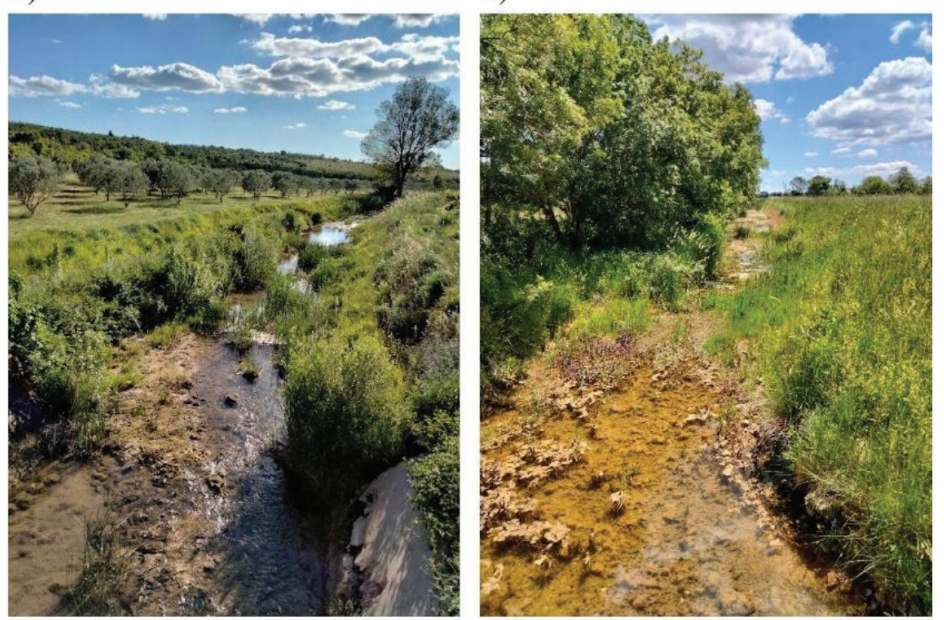

d)

Fig. 1. Examples of the study sites aloong four intermittent rivers in Croatia inhabited by rare mayflies: a) Krčić river (site 3, habitat of Nigrobaetis niger), b) Čikola river (site 1, habitat of Nigrobaetis niger and Procloeon pennulatum), c) Guduča river (site 2, habitat of Nigrobaetis niger) and d) Miljašić Jaruga river (site 2, habitat of Paraleptophlebia werneri).

and four in the Dinaric Western Balkan ecoregion (ER 5) (the Suha Ričina and Brodic Streams, and the Otuča and Vrba Rivers (Fig. 2a; Vilenica et al., 2015)). This species was reported from hypocrenal to epipotamal river sections (BUFFAGNi et al., 2009, 2021), most commonly from the rhithralic parts (BAUERnFEInd \& SOLDÁN, 2012), which was also the case in the Croatian watercourses (VILENICA et al., 2015, 2016). To our knowledge, the species is now recorded in IRES for the first time.

In the studied intermittent rivers, the highest abundances of $N$. niger were collected from macrophytes (Fig. 3a), but the species was also present on lithal and xylal (stony substrates and dead vegetation parts). The species is known as a microhabitat specialist for macrophytes, although it was also recorded from other substrates, such as micro/mesolithal (pebbles, boulders) and particulate organic matter (BuffaGNi et 

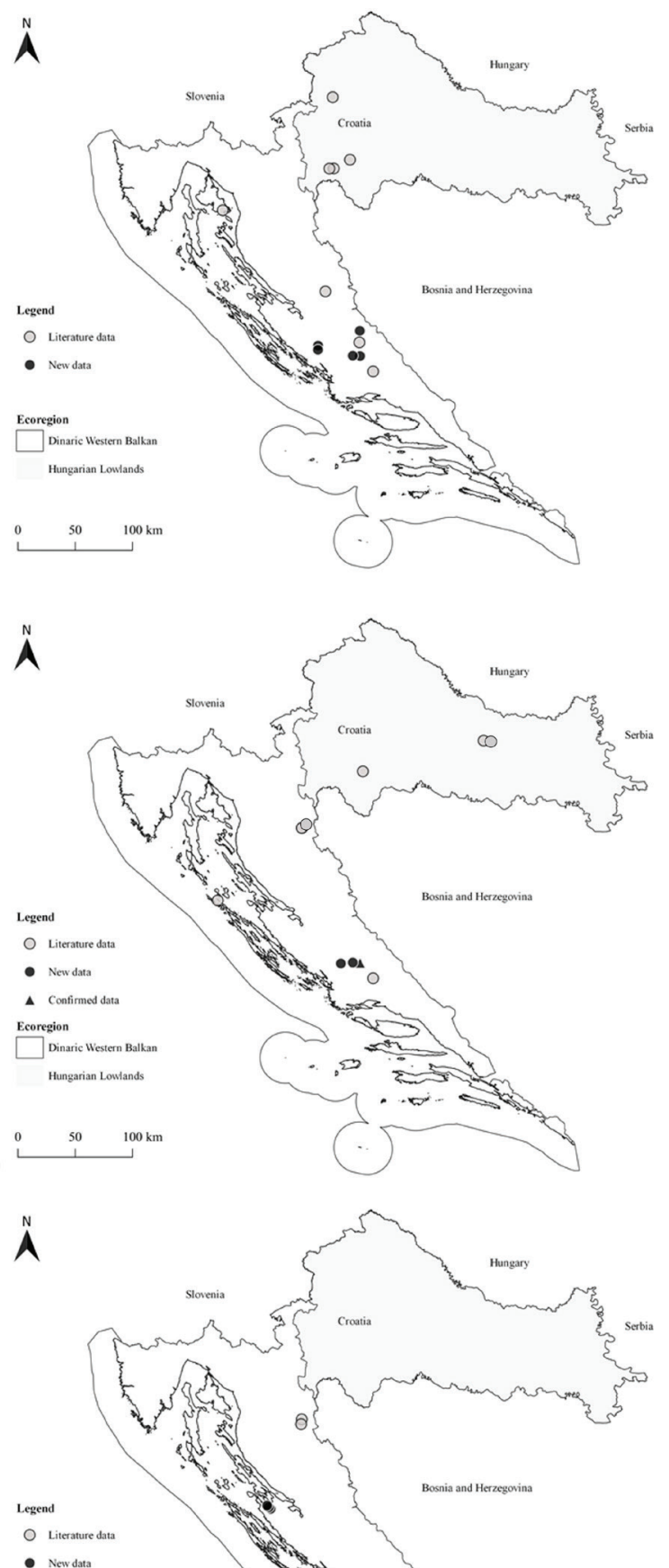

Ecoregion

$\square$ Ecoregion Hungarian Lostands $0 \quad 50 \quad 100 \mathrm{~km}$

c)
Fig. 2. Distribution maps (with literature records and new data) for three rare species recorded at four intermittent rivers in Croatia: a) Nigrobaetis niger, b) Procloeon pennulatum, c) Paraleptophlebia werneri. 


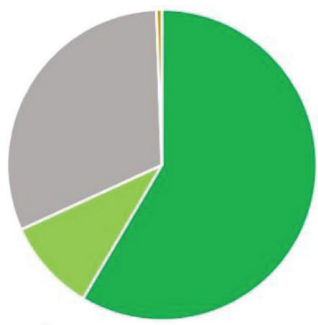

a)

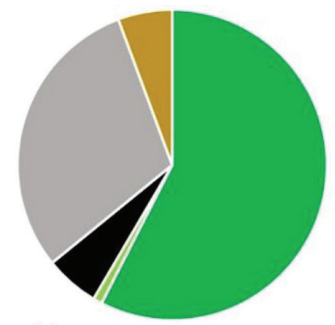

b)

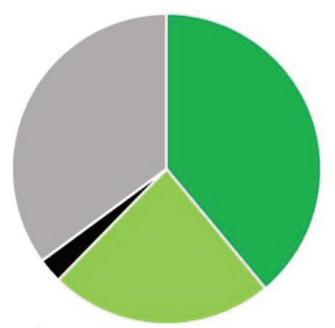

c)

- Angiosperms " Mosses - Fine sediment " Lithal " Xylal

Fig. 3. Species occurrence on the dominant substrate types in the four investigated intermittent rivers in Croatia: a) Nigrobaetis niger, b) Procloeon pennulatum, c) Paraleptophlebia werneri.

al., 2009, 2021). Abundance of N. niger was positively correlated with chemical oxygen demand $(R=0.364, p=0.011)$, nitrite concentration $(R=0.385, p=0.007)$ and alkalinity $(\mathrm{R}=0.299, \mathrm{p}=0.039)$; in the Čikola and Guduča Rivers it was most abundant at sites characterized by high anthropogenic pressure and the vicinity of farmland. These results could also indicate that $N$. niger is able to tolerate water pollution.

\section{Procloeon pennulatum (Eaton, 1870)}

During our study, we have collected rheo- to limnophile P. pennulatum only in the Čikola River, at all three sites (Fig. 2b). In Croatia, the species was recorded predominantly in ER5, where it was found at a total of five sites: the Plitvica Stream and the tufa barrier Novakovića Brod in the Plitvice Lakes National Park (VILEnICA et al., 2017b), the Lepenica Reservoir (VILENICA et al., 2020), and the Čikola and Vrba Rivers (VILENICA et al., 2015). Three sites are located in ER11: the Petrinjčica River (VILENICA et al., 2015) and the Ćeralinica and Djedovica Streams in Papuk Nature Park (Fig 2b; Vilenica et al., 2018b). Our current records confirm data presented in Vilenica et al. (2015), who already recorded the species at site 1 in the Ćikola River. Nevertheless, since these authors did not investigate other sites on this river, our records from the study sites 2 and 3 can be considered new (Fig. 1b). In Croatian freshwater habitats, the species was previously recorded from both lotic and lentic sites (rivers, streams, tufa barriers, reservoirs) (VILENicA et al., 2015, 2017b, 2018b). The species can be found at hypocrenal to metapotamal river sections (BUFFAGNi et al., 2009, 2021), although BAUERnfEInd \& SOLdán (2012) emphasize its preference for rhithralic sections of smaller brooks, where the nymphs can be found mostly in sections with very slow currents. The species was previously reported from intermittent streams (e.g. ARMITAGE \& BASs, 2013), and is listed as one of the taxa with traits that enable the species to resist drought, i.e. it can resist dry periods in the egg stage (MACAN, 1978; BuffaGNi et al., 2009, 2021).

The highest abundances of $P$. pennulatum were collected from macrophyte substrates (Fig. 3b), which corroborates previous findings regarding its microhabitat preferences (see also Buffagni et al., 2009, 2021). We have also recorded it from fine sediment (sand, mud, silt), xylal (dead parts of aquatic vegetation) and lithal (stony substrates) (Fig. 3b), similar to the studies that showed its occasional occurence its occasional occurrence on particulate organic matter, woody debris, micro/mesolithal 
(pebbles, gravel) and psammal (sand) (BuffaGni et al., 2009, 2021). The abundance of this species was positively correlated with water $\mathrm{pH}(\mathrm{R}=0.446, \mathrm{p}=0.001)$; it is known to prefer neutral to alkaline $\mathrm{pH}$ values (BuffaGNi et al., 2009, 2021). The negative correlations with oxygen saturation $(\mathrm{R}=-0.351, \mathrm{p}=0.014)$ and dissolved oxygen concentration $(\mathrm{R}=-0.377, \mathrm{p}=0.008)$ could be related to its preference for habitats with warm water $\left(>=18^{\circ} \mathrm{C}\right)$ (BufFaGNi et al., 2009, 2021), but also to its absence from well-oxygenated fast flowing intermittent rivers, such as the Krčić and Guduča Rivers. The species also showed a negative correlation with the concentration of phosphates in water $(\mathrm{R}=-0.623, \mathrm{p}=<0.001)$, which could reflect its potential sensitivity to agricultural pollution.

\section{Paraleptophlebia werneri Ulmer, 1920}

Rheophile P. werneri was recorded in only one intermittent river included in this study, the Miljašić Jaruga River (Figs. 1d, 2c), at all three study sites. The habitat choice of this species in Croatian waterbodies (VILENICA et al., 2014, and new data) is in accordance with the literature data, but this is the first time it was recorded from temporary habitats in Croatia. Prior to this research, it was recorded only at two sites in ER5: Plitvica Stream and Prošće Lake in the Plitvice Lakes National Park (Fig. 2c; Vilenica et al., 2014). The current results have increased the known distribution area of the species towards the south in ER5, while it remains unknown for ER11. The species was reported from epirhithral to epipotamal river sections, with a preference towards zones with moderate to high current. It was also often found in lentic habitats, such as fishponds (Buffagni et al., 2009, 2021; Bauernfeind \& Soldán, 2012). Paraleptophlebia werneri was frequently reported from waterbodies that dry out during the summer (BAUERnFEIND \& SOLDÁn, 2012; White et al., 2018), which is why it is among the species that are indicative of hydrological conditions, i.e. indicator species for temporary waterbodies (BRATTON, 1990; BUFFAGNi et al., 2009, 2021). The species is adapted to intermittent flows via the production of drought-resistant eggs (WRIGHT et al., 1984). Adaptations in oviposition, length of embryogenesis, egg quiescence, larval growth rate, current speed adaptation and habitat range are among the traits of this species listed as potentially advantageous in intermittent habitats (RĚZníčKovÁ et al., 2010).

Our data show that P. werneri is mostly abundant on macrophytes (Fig. 3c), which is in line with the data reported in literature (Buffagni et al., 2009, 2021; BAUERnfeInd \& SoldÁn, 2012). We also collected it from fine sediment and lithal (stony substrates) (Fig. 2), similar to previous studies that found the species on fine sediment and particulate organic matter (BuffaGni et al., 2009, 2021). The habitat choice of this species (lotic as well as lentic habitats) combined with its microhabitat preferences for macrophyte vegetation, could explain the negative correlation with water velocity in the studied intermittent rivers $(\mathrm{R}=-0.515, \mathrm{p}=<0.001)$. There are no data on temperature preferences of the species (BUFfaGni et al., 2009, 2021), but in our study its abundance was positively correlated with water temperature $(R=0.381, p=0.007)$. Positive correlations were recorded with oxygen saturation $(\mathrm{R}=0.574, \mathrm{p}=<0.001)$ and dissolved oxygen concentration $(\mathrm{R}=0.593, \mathrm{p}=<0.001)$ which could be related with species' preference for habitats with submerged aquatic macrophytes (BAUERNFEIND \& SOLDÁn, 2012), that are often rich in oxygen (e.g. Frodge et al., 1990). Positive correlations were also recorded between species abundance and phosphate concentration $(R=0.327, p$ 
$=0.023)$ and conductivity $(\mathrm{R}=0.546, \mathrm{p}=<0.001)$, which could indicate a tolerance to agricultural pollution, similar to $P$. pennulatum.

In conclusion, as most of the available literature data regarding the presented mayfly species occurrence in IRES was obtained from Central European habitats, our records in the Mediterranean Dinaric karst intermittent rivers can be considered new. To properly protect (intermittent) habitats and their biota, it is essential to have good knowledge of the species that inhabit them. Our results indicate the importance of IRES for maintaining local mayfly diversity, as they harbour environmental conditions adequate to provide habitats for several rare species. The results presented here could contribute to filling the gaps in our knowledge of the distribution and occurrence frequency of rare Croatian mayflies, as well as their ecological requirements, which could help in future assessments of the species' conservation status, both in the country and in their whole distribution area.

\section{ACKNOWLEDGEMENTS}

The authors would like to thank the Croatian Scientific Foundation for funding this research (UIP-2020-02-5385, DinDRY to A.B.). We kindly thank Vladimir Bartovsky and Marija Starčević for help with the sampling, Lana Židak and Lina Vinković for help with sorting the collected material and Ivka Štefanić for help with water chemistry analyses. Two anonymous reviewers are thanked for their comments and suggestions that helped to improve this paper.

Received July 12, 2021

\section{REFERENCES}

American Public Health Association (APHA), 1992: Standard Methods for the Examination of Water and Wastewater. 18th edition, Washington DC, p. 13.

Armitage, P. D. \& Bass J., 2013: Long-term resilience and short-term vulnerability of South. Winterbourne macroinvertebrates Proceedings of the Dorset Natural History \& Archaeological Society 134, 43-55.

Bauernfeind, E. \& Humpesch, U. H., 2001: Die Eintagsfliegen Zentraleuropas Bestimmung und Ökologie. Verlag Naturhistorisches Museum Wien, 1-239.

Bauernfeind, E. \& Soldán T., 2012: The mayflies of Europe (Ephemeroptera). Apollo Books. Ollerup, Denmark.

Bratton, J. H., 1990: A review of the scarcer Ephemeroptera and Plecoptera of Great Britain. Research \& survey in nature conservation. Nature Conservancy Council 29, 40.

Buffagni, A., Cazzola, M., López-Rodríguez, M. J., Alba-Tercedor, J. \& Armanini, D. G., 2009: Volume 3 - Ephemeroptera. In: Schmidt-Kloiber, A. \& Hering, D. (eds.) Distribution and Ecological Preferences of European Freshwater Organisms. Pensoft Publishers (Sofia-Moscow). p. 254.

Buffagni, A., Armanini, D. G., Cazzola, M., Alba-Tercedor, J., López-Rodríguez, m. J., Murphy, J., SanDin, L. \& Schmidt-Kloiber, A. 2021: Dataset "Ephemeroptera". www.freshwaterecology.info - the taxa and autecology database for freshwater organisms, version 7.0 (accessed on 28.09.2021).

Elliott, J. M., Humpesch, U. H. \& Macan, T. T., 1988: Larvae of the British Ephemeroptera: a key with ecological notes. Scientific Publications of the Freshwater Biological Association 49, 145.

Firmiano, K. R., Ligeiro, R., Macedo, D. R., Juen, L., Hughes, R. M. \& Callisto, M., 2017: Mayfly bioindicator thresholds for several anthropogenic disturbances in neotropical savanna streams. Ecological Indicators 74, 276-284. doi: 10.1016/j.ecolind.2016.11.033 
Frodge, J. D., Thomas, G. L., Pauley, G. B., 1990: Effects of canopy formation by floating and submergent aquatic macrophytes on the water quality of two shallow Pacific Northwest lakes. Aquatic Botany 38 (2-3), 231-248. https:/ / doi.org/10.1016/0304-3770(90)90008-9.

GLeick, P. H., 2003: Global freshwater resources: Soft-path solutions for the 21st century. Science 302, 1524-1528.

Larned, S. T., Datry, T., Arscott, D. B., \& Tockner, K., 2010: Emerging concepts in temporary-river ecology. Freshwater Biology 55, 717-738.

Leigh, C., Bonada, N., Boulton, A. J., Hugueny, B., Larned, S. T., Vander Vorste, R. \& Datry, T., 2016: Invertebrate assemblage responses and the dual roles of resistance and resilience to drying in intermittent rivers. Aquatic Sciences 78(2), 291-301.

MACAN, T. T., 1978: Life histories of four species of Ephemeroptera. Verhandlungen der Internationalen Vereinigung für theoretische und angewandte Limnologie 20, 2594-2498.

Narodne NOvine, broj 66/16, Plan upravljanja vodnim područjima 2016. - 2021.

QGIS.org, 2021: QGIS Geographic Information System. QGIS Association. http://www.qgis.org (Accessed on 5.10.2021.)

RězníčKovÁ, P., Soldán T, PAŘIL, P. \& ZAHRÁdKoví, S., 2010: Comparison of mayfly (Ephemeroptera) taxocenes of permanent and intermittent Central European small streams via species traits. Biologia (Bratisl) 65, 720-729.

Sartori, M. \& Brittain, J. E., 2015: Order Ephemeroptera. In: Thorp, J. \& Rodgers, D. C. (eds.) Thorp and Covich's Freshwater Invertebrates: Ecology and General Biology. 4th Edition, Academic Press, New York, p. 873-891.

State Geodetic Administration, 2020: Gazetteer of geographical names of the Republic of Croatia. http://rgi.dgu.hr/home/ (Accessed on 1.10.2021.)

Stubbington, R., Chadd, R., Cid., N., Csabai, Z., Miliša, M., Morais, M., Munné, A., Pařıl, P., Pešić, V., Tziortzis, I., Verdonschot, R. C. M. \& Thibault, D., 2018: Biomonitoring of intermittent rivers and ephemeral streams in Europe: Current practice and priorities to enhance ecological status assessments. Science of The Total Environment 618, 1096-1113. doi: 10.1016/j.scitotenv.2017.09.137

Skoulikidis, T. N., Sabater, S., Datry, T., Morais, M., Buffagni, A., Dörflinger, G., Zogaris, S., Sánchez-Montoya, M., Bonada, N., Kalogianni, E., Rosado, J., Vardakas, L., De Girolamo, A. M. \& TOCKNER, K., 2017: Non-perennial Mediterranean rivers in Europe: Status, pressures, and challenges for research and management. Science of the Total Environment 577, 1-18.

ŠEGOTA, T. \& FilipČı́c, A. 2003: Köppenova podjela klima i hrvatsko nazivlje. Geoadria 8(1), 17-23. (In Croatian).

TIBCO Software Inc. 2017: Statistica (data analysis software system), version 13. http:/ / statistica.io

Tockner, K., Robinson, C. T. \& Uehlinger, U., 2009: Rivers of Europe. 1st Edition. Academic Press, San Diego, p. 728.

Vilenica, M., Gattolliat, J.-L., Ivković, M., Kučinić, M., Mičetić Stanković, V., Mihaljević, Z. \& SARTORI, M., 2014: The mayfly fauna (Insecta, Ephemeroptera) of the Plitvice Lakes National Park, Croatia. Natura Croatica 23 (2), 349-363.

Vilenica, M., Gattolliat, J.-L., Mihaljević, Z. \& Sartori, M., 2015: Croatian mayflies (Insecta, Ephemeroptera): species diversity and distribution patterns. ZooKeys 523, 99-127. doi: 10.3897/ zookeys.523.6100.

Vilenica, M., Brigić, A., Kerovec, M., Gottstein, S. \& Ternjej, I., 2016: Spatial distribution and seasonal changes of mayflies (Insecta, Ephemeroptera) in a Western Balkan peat bog. ZooKeys 637, 135-149. doi: 10.3897 / zookeys.637.10359

Vilenica, M., Mičetić Stanković, V., Sartori, M., Kučinić, M. \& Mihaljević, Z., 2017a: Environmental factors affecting mayfly assemblages in tufa-depositing habitats of the Dinaric Karst. Knowledge and Management of Aquatic Ecosystems 418 (14), 1-12 doi: 10.1051/kmae/2017005.

Vilenica, M., Ivković, M., Sartori, M. \& Mihaljević, Z., 2017b: Mayfly emergence along an oligotrophic Dinaric karst hydrosystem: spatial and temporal patterns, and species-environment relationship. Aquatic Ecology 51, 417-433. doi: 10.1007/s10452-017-9626-3.

Vilenica, M., Brigić, A., Sartori, M. \& Mihaljević, Z., 2018a: Microhabitat selection and distribution of functional feeding groups of mayfly larvae (Ephemeroptera) in lotic karst habitats. Knowledge and Management of Aquatic Ecosystems 419(17), 1-12 doi: 10.1051/kmae/2018011 q2 
Vilenica, M., Ergović, V. \& Mihaljević, Z., 2018b: Mayfly (Ephemeroptera) assemblages of a Pannonian lowland mountain, with first records of the parasite Symbiocladius rhithrogenae (Zavrel, 1924) (Diptera: Chironomidae). Annales de Limnologie - International Journal of Limnology 54 (31), 1-10. doi:10.1051/limn/2018023

Vilenica, M., VučKović, N. \& Mihaljević, Z., 2019: Littoral mayfly assemblages in South-East European man-made lakes. Journal of limnology 70(1), 1-13. doi: 10.4081/jlimnol.2019.1853

Vilenica, M., Kerovec, M., Pozojević, I. \& Mihaljević, Z., 2020: Mayfly response to different stress types in small and mid-sized lowland rivers. ZooKeys 980, 57-77 doi: 10.3897/zookeys.980.54805

Vilenica, M., Ternjej, I. \& Mihaljević, Z., 2021: What is new in Croatian mayfly fauna? Natura Croatica 30 (1), 73-83. doi: 10.20302/NC.2021.30.6

Waltz, R. D., McCafferty, W. P. \& Thomas, A., 1994: Systematics of Alainites n.gen., Diphetor, Indobaetis, Nigrobaetis, n.stat., and Takobia n.stat. (Ephemeroptera, Baetidae). Bulletin de la Société d'histoire naturelle de Toulouse 130, 33-36.

White, J. C., House, A., Punchard, N., Hannah, D. M., Wilding, N. A., Wood, P. J., 2018: Macroinvertebrate community responses to hydrological controls and groundwater abstraction effects across intermittent and perennial headwater streams. Science of The Total Environment 610, 1514-1526. doi: 10.1016/j.scitotenv.2017.06.081.

Wright, J. F., Hiley, P. D., Cooling, D. A., Cameron, A. C., Wigham, M. E. \& Berrie, A. D., 1984: The invertebrate fauna of a small chalk stream in Berkshire, England, and the effect of intermittent flow Arch. Hydrobiology, 99 (2), 176-199.

Zaninović, K., Gajić-Čapka, M., Perčec Tadić, M., Vučetić, M., Milković, J., Bajić, A., Cindrić, K., Cvitan, L., Katušin, Z., Kaučić, D., Likso, T., Lončar, E., Lončar, Ž., Mihajlović, D., Pandžić, K., Patarčić, M., Srnec, L., Vučetić, V., 2008: Klimatski atlas Hrvatske / Climate atlas of Croatia 1961-1990., 1971-2000. Državni hidrometeorološki zavod, Zagreb.p. 1-200. (In Croatian). 